\title{
A Study of Butterfly Species Diversity in M. N. College Campus, Visnagar, Mehsana District, Gujarat, India
}

\author{
Surbhi Dabhadkar ${ }^{*}$, Rakesh Prajapati ${ }^{2}$ \\ ${ }^{1}$ Student, Department of Life Sciences, Hemchandracharya North Gujarat University, Patan, India \\ ${ }^{2}$ Assistant Professor, Department of Biology, M. N. College, Visnagar, India \\ *Corresponding author: surbhidabhadkar@gmail.com
}

\begin{abstract}
The present study was carried out to understand the butterfly diversity and abundance in $M$. N. College, Visnagar, Gujarat, India from November 2019 to March 2020. A total of 40 species of butterflies belonging to 29 genera and five families were recorded from the present study. From the observed butterflies, family Pieridae was the most dominant among the five families with 14 species, followed by Nymphalidae comprising of 9 species, Lycaenidae have 9 species, Papilionidae with 5 species and Hesperidae with 3 species. The present study added valuable information on diversity of butterfly fauna and will contribute in developing effective conservation.
\end{abstract}

Keywords: Butterfly, Biodiversity.

\section{Introduction}

Butterflies belong to the order Lepidoptera and are one of the most colourful, widespread and easily identifiable class of insects. They are potentially useful ecological indicators of urbanization because sensitive to changes in microclimate, temperature and extremely important components of the bioindicators of the world. Butterflies (Lepidoptera: Rhopalocera) are important and attractive insects that support human society economically and ecologically. Butterflies are nature's messengers, not only bringing brilliance to their world, but also pollinating flowers and exposing our community 's wellbeing.

\section{Material and Method}

M. N. College is located at Visnagar taluka in Mehsana district, Gujarat, India. M. N. College campus lies at $23^{\circ} 41^{\prime} 55^{\prime}$ 'N and $72^{\circ} 32^{\prime} 16^{\prime \prime} \mathrm{E}$. This campus falls in 42 acres of area. Having 7 pollinating areas here. I used point count method for this study. My study period was from November 2019 to March 2020. I have total data of 5 months. I observed and captured pictures every day. The time of observation was from 9:00 am to 4:00 pm. I took observations in morning and evening time. The record of individual butterflies was taken at the time of appearance to me. I used digital camera of 1300D and 700D along with the zoom lens (CANON ZOOM LENS EF-S 55 $250 \mathrm{~mm}$ and CANON ZOOM LENS EF-S $18-55 \mathrm{~mm}$ ). The recorded butterfly species were identified with the help of photographs by using manual books, available research papers, articles and with the help of experts. For identification of species of butterflies, I used Butterflies of India by Peter Smetacek and A pictorial field guide to Butterflies of Forest Campus, Coimbatore by Ruchi Dave.

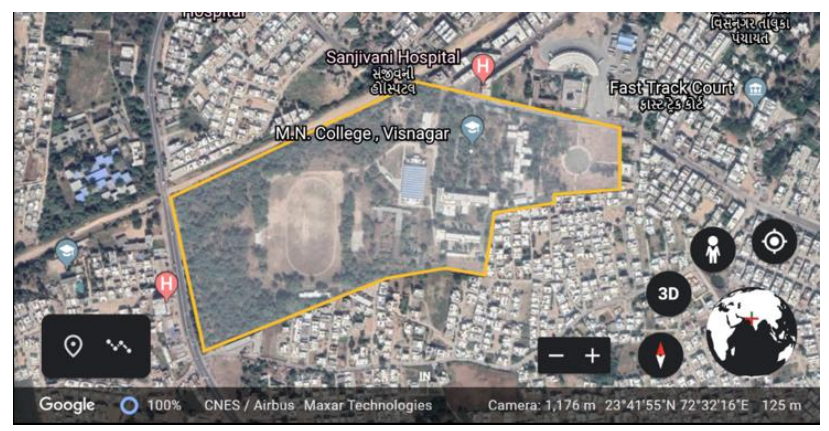

Fig. 1. Google image of study site

\section{Result and Discussion}

I recorded total 40 butterfly species during my study of area M. N. College Campus, Visnagar, Mehsana, Gujrat, India. Total number of 40 individual's species of butterflies belonging within five (5) families and total twenty-nine 29 genera recorded till March, 2020. The family Pieridae (14) was the dominant contributing family followed by Nymphalidae (9), Lycaenidae (9), Papilionoidae (5) and Hesperiidae (3) with individuals being the least. This study shows that M. N. College Campus, Visnagar possesses around 40 species of butterfly. Having 7 seven pollinating area in college campus. Butterfly diversity is different with season.

According to similar study Aishwarya V. Nair and Pradarsika Mitra., (2014) they found total 46 species of butterfly around Sarojini Naidu college campus, Kolkata, West Bengal, India. They studied on butterfly diversity and abundance. The preference of butterflies for particular habitats is connected with the availability of host plants and nectar plants. Butterfly helps in pollination of the plants by acting as a carrier of the pollen from the flower that it visits and hence helping in 


\section{IJRESM https://www.ijresm.com | ISSN (Online): $2581-5792$}

development of new plants and M. N. College campus has huge diversity of plants and also has huge diversity of different types of butterfly species so this study was done to make awareness of pollinators in students and locals.

Table 1

List of observe butterfly species in M. N. College Campus, Visnagar

\begin{tabular}{|c|c|c|}
\hline S. No. & Common Name & Scientific Name \\
\hline \multicolumn{3}{|c|}{ Family: Pieridae } \\
\hline 1. & Small Salmon Arab & Colotis amata \\
\hline 2. & White Arab & Colotis phisadia \\
\hline 3. & Common Emigrant & Catopsilia pomona \\
\hline 4. & Mottled Emigrant & Catopsilia pyranthe \\
\hline 5. & Common Grass Yellow & Eurema hecabe \\
\hline 6. & Spotless Grass Yellow & Eurema laeta \\
\hline 7. & Three Spot Grass Yellow & Eurema blanda \\
\hline 8. & Yellow Orange Tip & Ixias pyrene \\
\hline 9. & White Orange Tip & Ixias marianne \\
\hline 10. & Crimson Tip & Colotis danae \\
\hline 11. & Pioneer & Belenois aurota \\
\hline 12. & Common Gull & Cepora nerissa \\
\hline 13. & Common Jezebel & Delias eucharis \\
\hline 14. & Common Albatross & Appias albina \\
\hline \multicolumn{3}{|c|}{ Family: Nymphalidae } \\
\hline 15. & Great Egg Fly & Hypolimnas bolina \\
\hline 16. & Danaid Egg Fly & Hypolimnas misipus \\
\hline 17. & Plain Tiger & Danaus chrysippus \\
\hline 18. & Blue Tiger & Tirumala limniace \\
\hline 19. & Blue Pansy & Junonia orithya \\
\hline 20. & Peacock Pansy & Junonia almanac \\
\hline 21. & Lemon Pansy & Junonia lemonias \\
\hline 22. & Tawny Coaster & Acraea violae \\
\hline 23. & Common Evening Brown & Melanitis leda \\
\hline \multicolumn{3}{|c|}{ Family: Lycaenidae } \\
\hline 24. & Plain Cupid & Luthrodes pandava \\
\hline 25. & Small Cupid & Chilades parrhasius \\
\hline 26. & Zebra Blue & Leptotes plinius \\
\hline 27. & Fore-Get-Me-Not & Catochrysops Strabo \\
\hline 28. & Tiny Grass Blue & Zizula hylax \\
\hline 29. & Pale Grass Blue & Pseudozizeeria maha \\
\hline 30. & Lesser Grass Blue & Zizinia otis \\
\hline 31. & Dark Grass Blue & Zizeeria karsandra \\
\hline 32. & Grass Jewel & Freyeria trochylus \\
\hline \multicolumn{3}{|c|}{ Family: Papilionidae } \\
\hline 33. & Common Jay & Graphium doson \\
\hline 34. & Tailed Jay & Graphium agamemnon \\
\hline 35. & Common Mormon & Papilio polytes \\
\hline 36. & Common Rose & Pachliopta aristolochiae \\
\hline 37. & Lime & Papilio demoleus \\
\hline \multicolumn{3}{|c|}{ Family: Hesperiidae } \\
\hline 38. & Indian Skipper & Spialia galba \\
\hline 39. & Indian Palm Bob & Suastus gremius \\
\hline 40. & Common Banded Awl & Hasora chromus \\
\hline
\end{tabular}

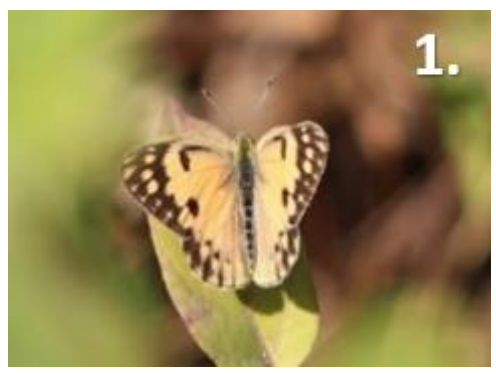

Fig. 2. Small Salmon Arab

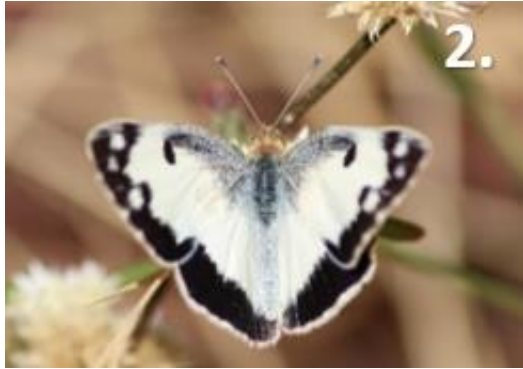

Fig. 3. White Arab

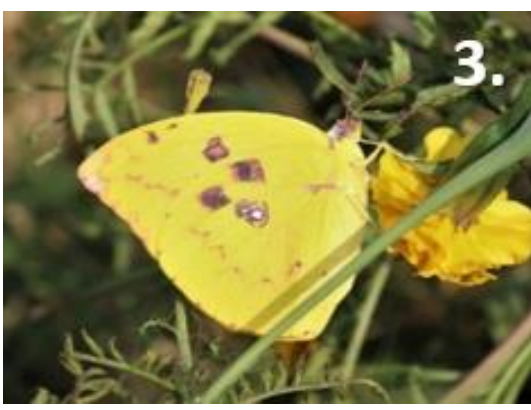

Fig. 4. Common Emigrant

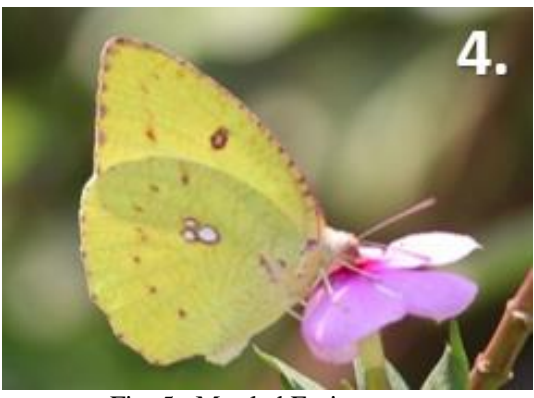

Fig. 5. Mottled Emigrant

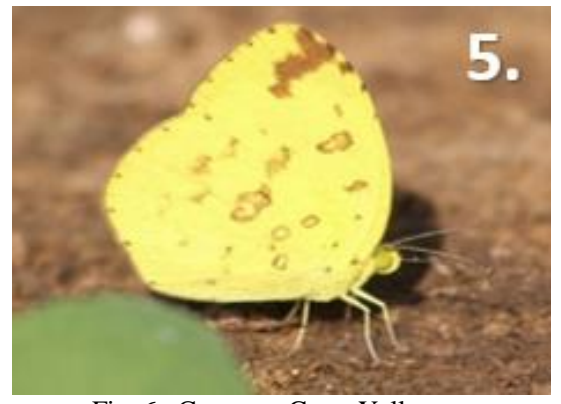

Fig. 6. Common Grass Yellow

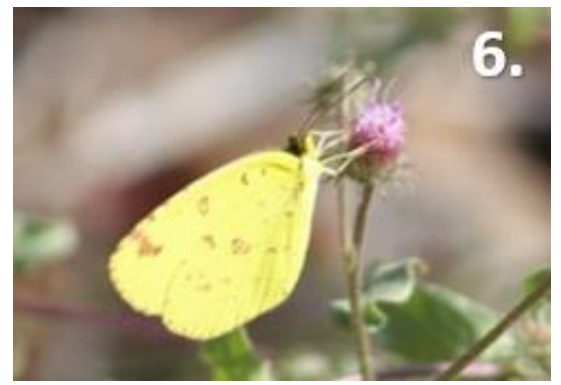

Fig. 7. Three Spot Grass Yellow 
Volume-3, Issue-12, December-2020

https://www.ijresm.com | ISSN (Online): 2581-5792

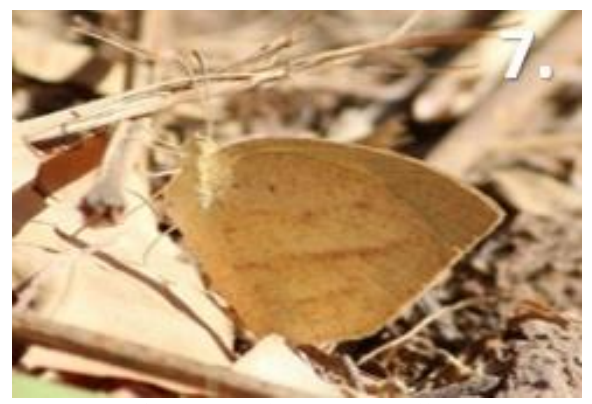

Fig. 8. Spotless Grass Yellow

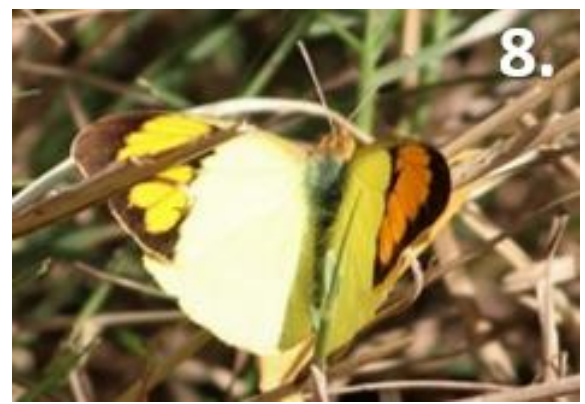

Fig. 9. Yellow Orange Tip

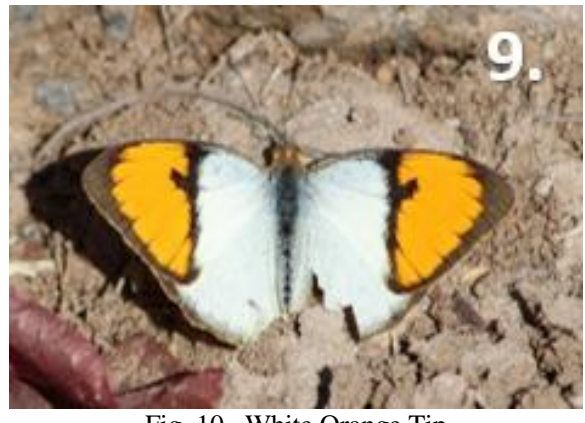

Fig. 10. White Orange Tip

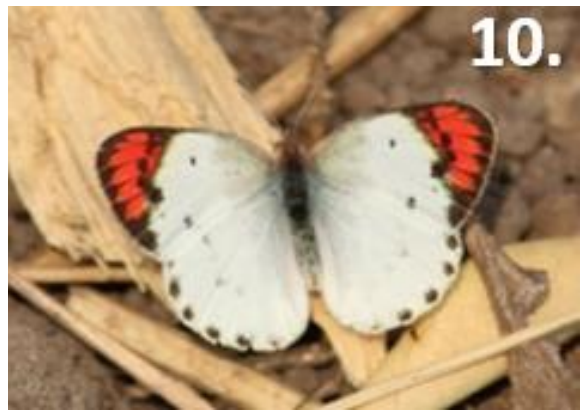

Fig. 11. Crimson Tip

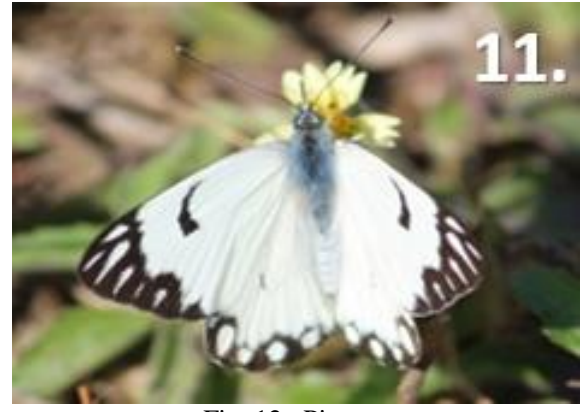

Fig. 12. Pioneer

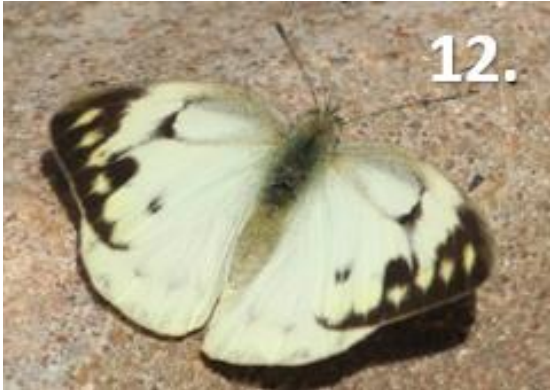

Fig. 13. Common Gull

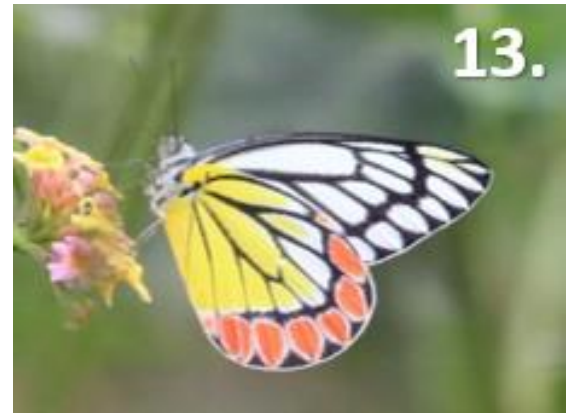

Fig. 14. Common Jezebel

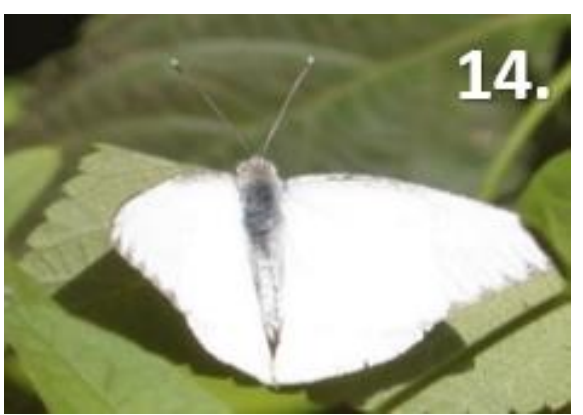

Fig. 15. Common Albatross

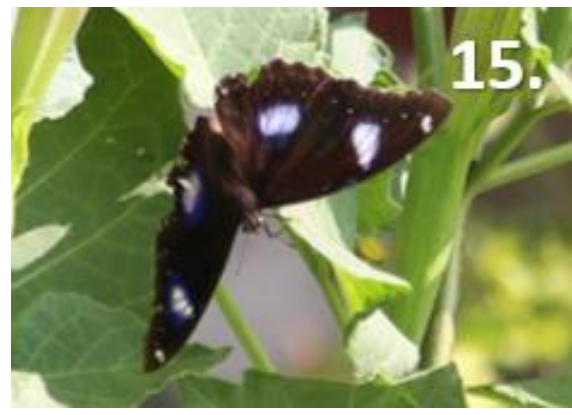

Fig. 16. Great Eggfly

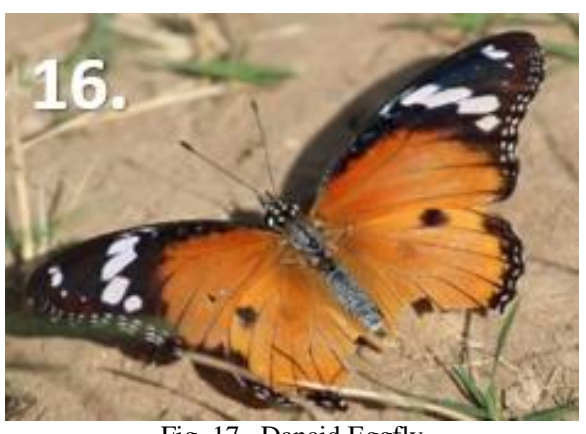

Fig. 17. Danaid Eggfly 
Volume-3, Issue-12, December-2020

https://www.ijresm.com | ISSN (Online): 2581-5792

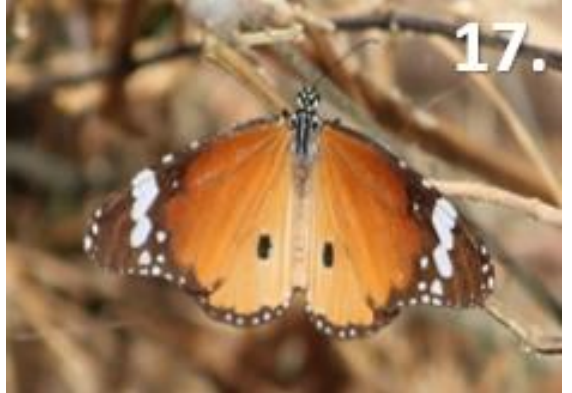

Fig. 18. Plain Tiger

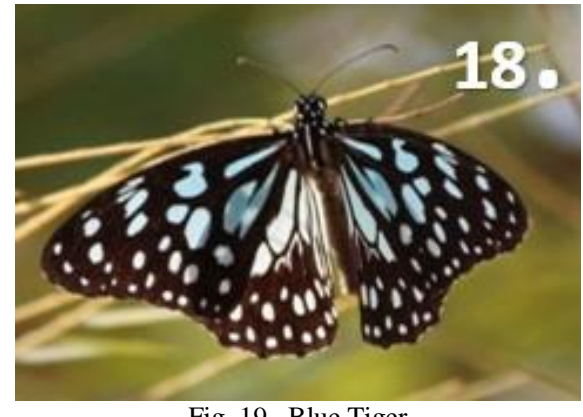

Fig. 19. Blue Tiger

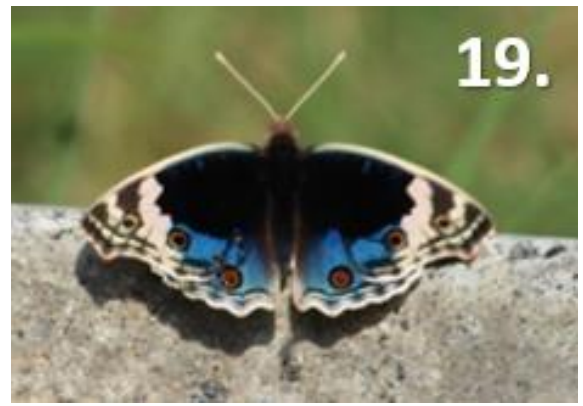

Fig. 20. Blue Pansy

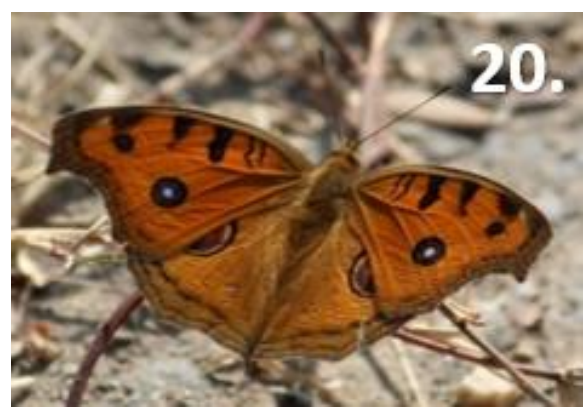

Fig. 21. Peacock Pansy

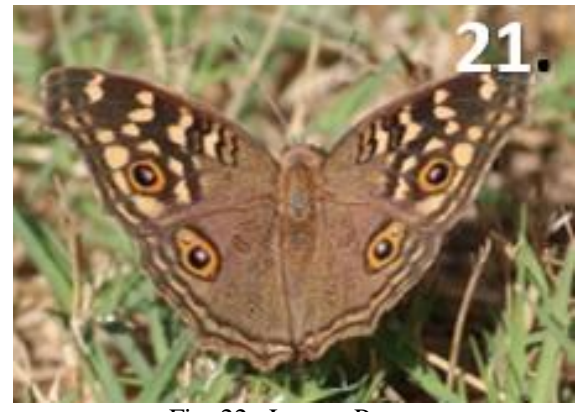

Fig. 22. Lemon Pansy

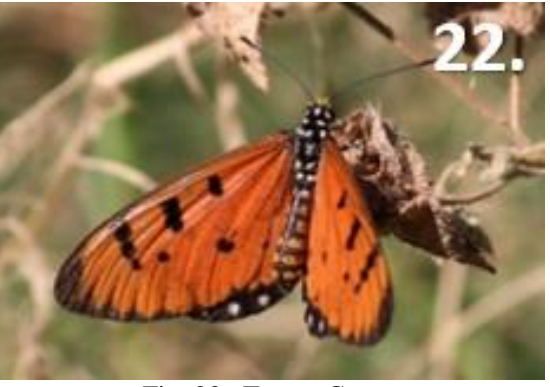

Fig. 23. Tawny Coster

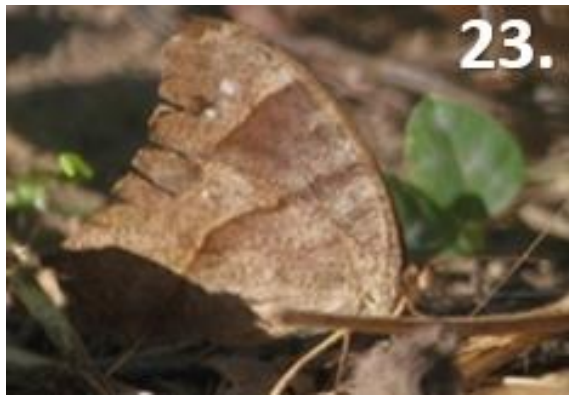

Fig. 24. Common Evening Brown

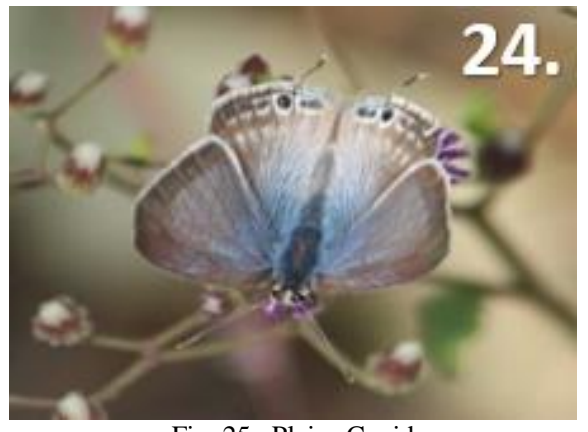

Fig. 25. Plains Cupid

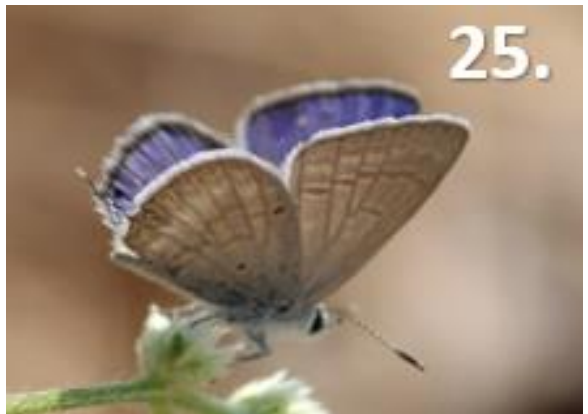

Fig. 26. Small Cupid

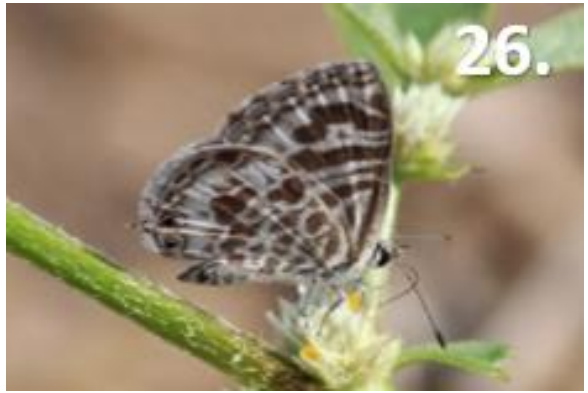

Fig. 27. Zebra Blue 


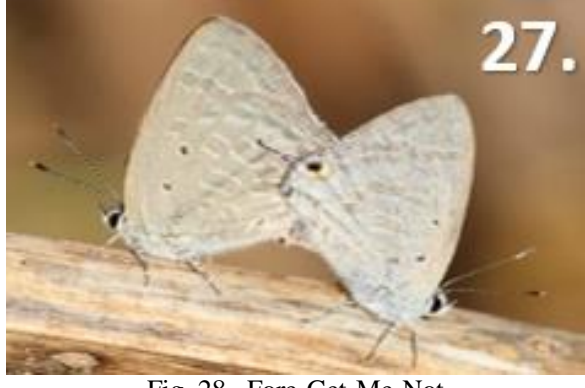

Fig. 28. Fore-Get-Me-Not

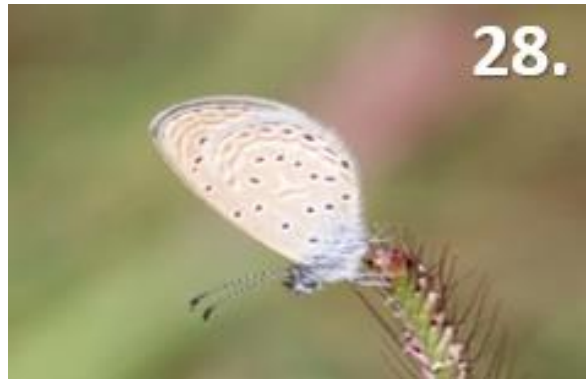

Fig. 29. Tiny Grass Blue

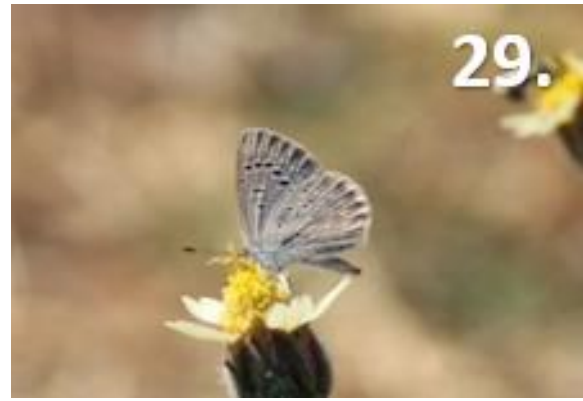

Fig. 30. Pale Grass Blue

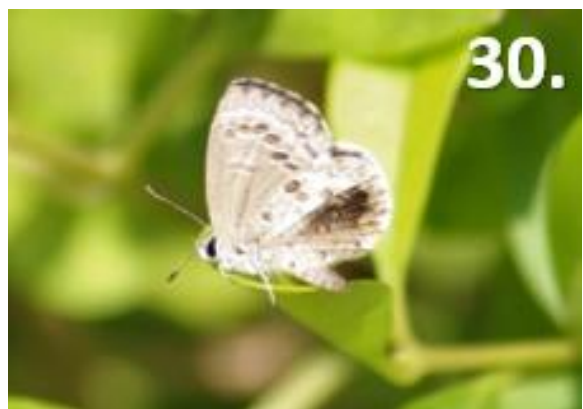

Fig. 31. Lesser Grass Blue

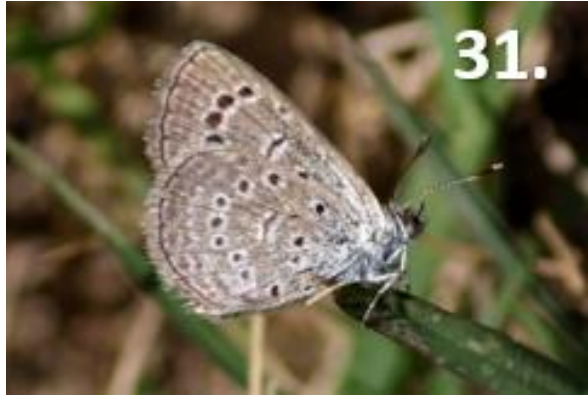

Fig. 32. Dark Grass Blue

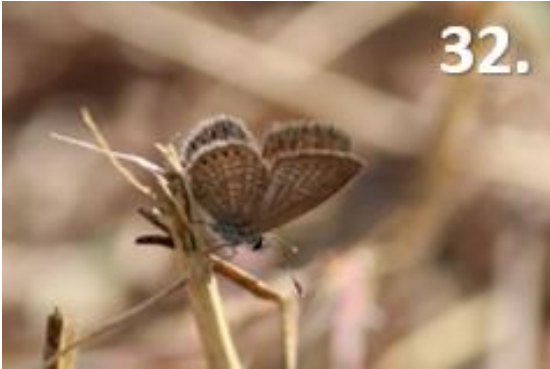

Fig. 33. Grass Jewel

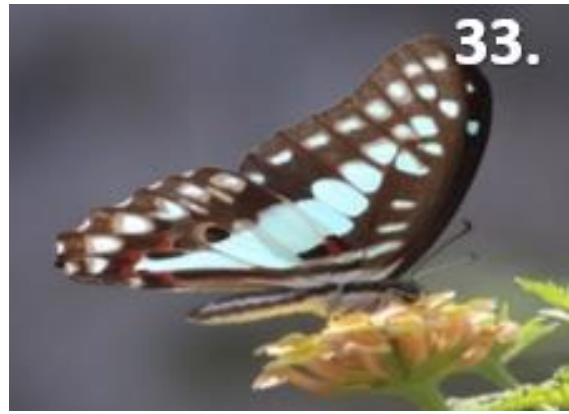

Fig. 34. Common Jay

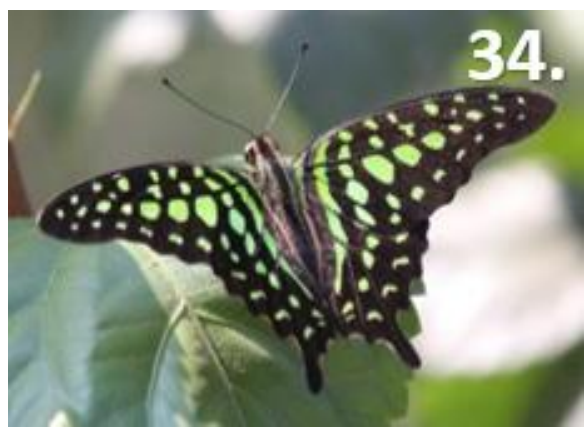

Fig. 35. Tailed Jay

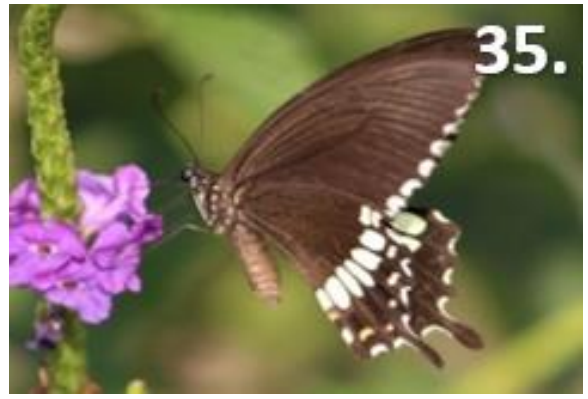

Fig. 36. Common Mormon

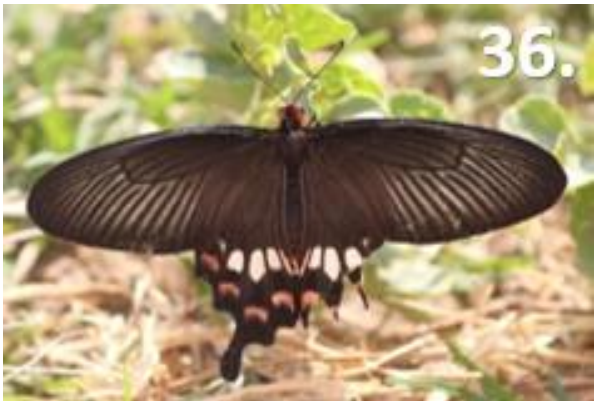

Fig. 37. Common Rose 


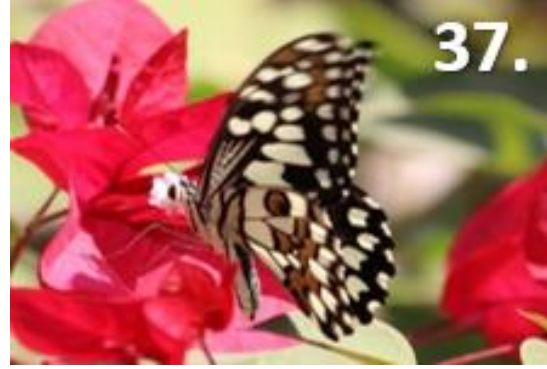

Fig. 38. Lime

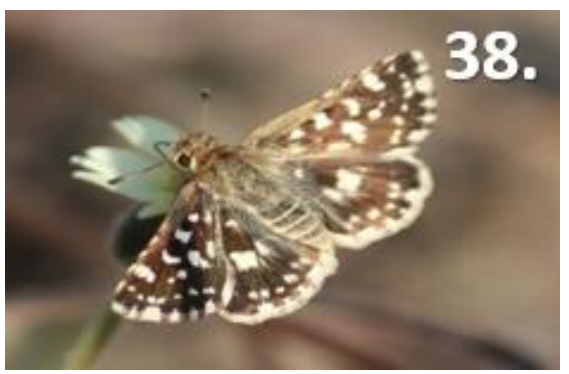

Fig. 39. Indian Skipper

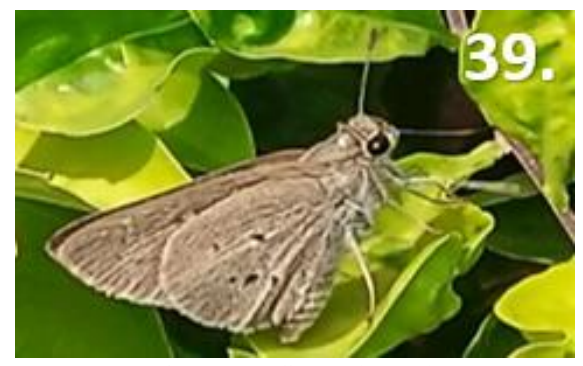

Fig. 40. Indian Palm Bob

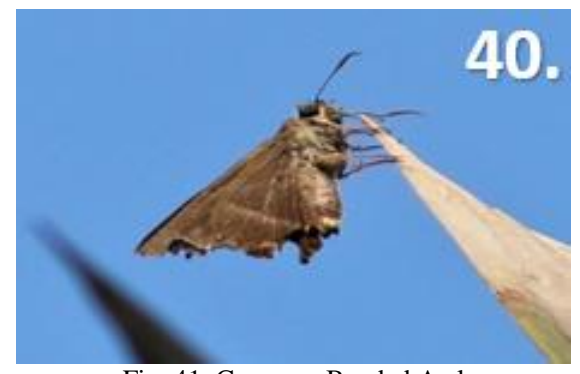

Fig. 41. Common Banded Awl

\section{Conclusion}

Butterflies maintain the ecosystem by acting as pollinator, prey, biological pest control, make genetic variation in plants, and increase environmental beauty, decrease the level of carbon dioxide in air. The findings of the present study highlight the importance of recognized campuses as a perfect habitat for butterflies. If the improving and care of gardens are carefully planned, the diversity of butterflies may increase in our college campus providing a rich ground for butterfly conservation as well as for research. This study will also add to our future attempts in understanding the complex nature of mutualistic contact between butterflies and flowering plants that is important for continuity of ecosystem services.

\section{Acknowledgement}

I am very thankful to my guide Dr. Rakesh Prajapati, Assistant Professor, Department of Biology, M. N. College, Visnagar for given me an excellent and perfect guidance at any moment during this work. I also indebted for his suggestion and constructive comments which enabled me to complete this work in time. I own my success to him.

\section{References}

[1] Thomas, J. A., D. J. Simcox, J. C. Wardlaw, G. W. Elmes, M. E. Hochberg, and R. T. Clarke. "Effects of latitude, altitude and climate on the habitat and conservation of the endangered butterfly Maculinea arion and its Myrmica ant hosts." Journal of Insect Conservation 2, no. 1, pp. 39-46, March 1998.

[2] Chakravarthy AK, Rajagopal D. and Jagannatha R., "Insects as bioindicators of conservation in the tropics". Zoo's print J, no. 12, pp. 2125, 1997.

[3] Alfred, J. R. B., A. K. Das, and A. K. Sanyal. "Faunal diversity in India." ENVIS Centre. Zoological Survey of India, Kolkata, pp. 495, 1998.

[4] Basavarajappa, S., \& Santhosh, S., "Butterfly species composition and diversity in a protected area of Karnataka, India", International journal of biodiversity and conservation, vo.10, no.10, pp. 432-443, 2018.

[5] Bindulekha, D. S. \& Amalnath, S., "A Preliminary Study on the Biodiversity of Insects Collected from A College Campus: Thiruvananthapuram District, Southern Kerala", International Journal of Science and Research (IJSR), vol. 6, pp. 1631-1634, 2017.

[6] Borges RM, Gowda V and Zacharias M. "Butterfly pollination and high contrast visual signals in a low density distylous plant", Oceologia, 36:571-573, 2001.

[7] Chakravarthy AK, Rajagopal D. and Jagannatha R. "Insects as bioindicators of conservation in the tropics", Zoo's print J, 12: 21-25, 1997.

[8] Chettri, B. "A study on the distribution pattern and conservation of amphibians in Sikkim, India." Final Report submitted to Ashoka Trust for Research in Ecology and Environment, Darjeeling, India (2010).

[9] Choudhary, A., Ahi, J., "A review: Biodiversity of freshwater insects", Int. J. Eng. Sci., 4(10), 25-31, 2015

[10] Danks, H. V. "How to assess insect biodiversity without wasting your time", Biological Survey of Canada (Terrestrial Arthropods), Document Series No. 5, (1996).

[11] De Souza, Paulo Ricardo Barbosa, and Rhainer Guillermo-Ferreira. "Butterflies of the bodoquena plateau in Brazil (Lepidoptera, Papilionoidea)." ZooKeys 546 (2015): 105.

[12] Ditchkoff, S., "Biodiversity and ecosystem management, Oklahoma State University", 21(1), 2016.

[13] Elanchezhyan, K., Samraj, J. M., \& Reuolin, S. J. "Butterfly diversity at the agricultural college campus, Killikulam, Tami Nadu, India", Journal of Entomology and Zoology Studies, 5(5), 1389-1400, 2017.

[14] Finnamore, A.T., "The advantages of using arthropods in ecosystem management", A brief from the Biological Survey of Canada (Terrestrial Arthropods), 11 pp, 1996.

[15] Ganvir, D. R., \& Khaparde, K. P., "Seasonal Diversity and Status of Butterfly Fauna in Sakoli Taluka of Bhandara District, Maharashtra, India", Int. J. Life. Sci. Scienti. Res. eISSN, 2455(1716), 1716, 2018.

[16] Ghazanfar, M., Malik, M. F., Hussain, M., Iqbal, R., \& Younas, M., "Butterflies and their contribution in ecosystem: A review. Journal of Entomology and Zoology Studies", 4(2), 115-118, 2016.

[17] Ghosh, A.K., "Insect biodiversity in India", Ori. Insect. 30 (1), 1996.

[18] Gohel, V. H., \& Raval, J. V., "Butterfly Diversity, Seasonality and Status at Junagadh, Gujarat, India", International Journal of Environment, Ecology, 9, 15-28, 2019.

[19] Gokarnkar, P., Chorghe, S. V., \& Rajbhor, A., "Butterfly Diversity of Maharashtra Nature Park", In Proceedings of the Seminar on Wonderful World of Insects. Thane: Department of Zoology, VPM's BN Bandodkar College, 63-64, 2008.

[20] Guptha, M. B., Rao, P. C., Reddy, D. S., Maddala, S. R. S. C. S., \& Babu, P. M., "A preliminary observation on butterflies of Seshachalam 
Biosphere Reserve, Eastern Ghats, Andhra Pradesh, India", World Journal of Zoology, 7(1), 83-89, 2012.

[21] Harsh, S., "Butterfly diversity of Indian institute of forest management, Bhopal, Madhya Pradesh, India", Journal of Insects, 2014.

[22] Jana S, Pahari PR, Dutta TK and Bhattacharya T., "Diversity and community structure of aquatic insects' pond in Midnapore town, West Bengal”, India. J. Environmental Biology, 30: 283-287, 2009

[23] Jayakumar, M., Raja, M., \& William, S. J., "Biodiversity of insect and conservation" In Proc.: National conference on, 2006

[24] Kulshrestha, R., Jain, N., "A note on the biodiversity of insects collected from a college campus of Jhalawar district, Rajasthan", Biosci. Biotech. Res. Comm., 9(2), 327-330, 2016.

[25] Majumder, J., \& Lodh, R., "Inventory of butterfly fauna (Lepidoptera: Rhopalocera) of Tripura, India in the Indo-Myanmar biogeographical zone, with records of threatened taxa", Check List, 11, 1, 2015.

[26] Nair, A. V., Mitra, P., \& Bandyopadhyay, S. A., "Studies on the diversity and abundance of butterfly (Lepidoptera: Rhopalocera) fauna in and around Sarojini Naidu College campus, Kolkata, West Bengal, India”, Journal of Entomology and Zoology Studies, 2(4), 129-134, 2014.

[27] Robbins RK, Opler PA., "Biodiversity II, understanding and protecting our biological resources". Joseph Henry Press, Washington DC, 1997.

[28] Samways, M.J., "Insect Conservation”, EOLSS Publications, 1994.

[29] Schmidt BC and Roland J. Moth diversity in "A fragmented habitat: importance of functional groups and landscape scale in the boreal forest",
Annals of the Entomological Society of America, 99 (6): 1110-1120, 2006.

[30] Shwetha Alavandi, M. S., "A Priliminary Observation On Diversity Of Butterflies Of Shivgangotri Campus, Davangere University", International Journal of Agricultural Science and Research, (7), 273-280, 2019.

[31] Spellerberg, I. F., Fedor, P.J., “A tribute to Claude Shannon (1916-2001) and a plea for more rigorous use of species richness", species diversity and the Shannon- Wiener „Index. Global Eco. Biogeo, 2(3), 177-179, 2003.

[32] Thomas JA, Simcox DJ, Wardlaw JC, Elmes, WG, Hochberg, ME and Clark, RT., "Effects of latitude, altitude and climate on the habitat and conservation of the endangered butterfly Maculinea arion and its Myrmica ant host", J Sect conserve, 2: 39-46, 1998.

[33] Tiple AD., "Butterflies of Vidarbha region Maharashtra, India; a review with and implication for conservation", Journal of Threatened Taxa, 3(1): 1469-1477, 2011.

[34] Smetacek, P., "A Naturalist's Guide to the Butterflies of India, Pakistan, Nepal, Bhutan, Bangladesh and Sri Lanka", John Beaufoy Publishing Limited, 2017.

[35] https://www.google.com/maps/place/M.N.+College+,+Visnagar/@23.69 $90657,72.5364618,17 \mathrm{z} / \mathrm{data}=! 3 \mathrm{~m} 1 ! 4 \mathrm{~b} 1 ! 4 \mathrm{~m} 5 ! 3 \mathrm{~m} 4 ! 1 \mathrm{~s} 0 \times 395 \mathrm{c} 4 \mathrm{fe} 15 \mathrm{dc} 519$ 03:0x9410545dbc176b25!8m2!3d23.6990657!4d72.5386505 